\title{
IMMUNOHISTOCHEMICAL EXPRESSION OF MARKERS Ki-67, NeuN, SYNAPTOPHYSIN, P53 AND HER2 IN MEDULLOBLASTOMA AND ITS CORRELATION WITH CLINICOPATHOLOGICAL PARAMETERS
}

\author{
Rosalva Thereza Meurer', Daniele Tondolo Martins', Arlete Hilbig', Marlise de Castro Ribeiro 4 \\ Adriana Vial Roehe ${ }^{5}$, Ligia Maria Barbosa-Coutinho ${ }^{6}$, Marilda da Cruz Fernandes ${ }^{7}$
}

\begin{abstract}
Medulloblastoma (MB) is the most common malignant brain tumor in childhood. The alterations found include: presence of oncoproteins p53 and HER2, elevated mitotic index, and presence of neuronal differentiation. The aim of this study was to determine the immunohistochemical expression of markers $\mathrm{Ki}-67, \mathrm{NeuN}$, synaptophysin, HER2 and p53 in $40 \mathrm{MB}$ samples and their correlation with clinicopathologic parameters and survival. In 29 patients (72.5\%), $\geq 20 \%$ of cells were positive for Ki-67. Males showed greater ki-67 expression $(p=0.02)$ and smaller survival rates $(p=0.002)$. NeuN and synaptophysin were negative in 16 $(40 \%)$ and $8(20 \%)$ cases, respectively. P53 was positive in $18(45 \%)$ cases, with $11(61 \%)$ weakly positive and 7 $(39 \%)$ strongly positive. HER2 was positive in $23(57.5 \%)$ of the samples and did not show statistical association with survival $(\mathrm{p}=0.07)$.
\end{abstract}

KEY WORDS: medulloblastoma, immunohistochemistry, Ki-67, NeuN, synaptophysin, HER2, p53, survival analysis.

\begin{abstract}
Expressão imunoistoquímica dos marcadores Ki-67, NeuN, sinaptofisina, P53 e HER2 em meduloblastoma e sua correlação com os parâmetros clínico-patológicos

Resumo - Meduloblastoma (MB) é o tumor maligno encefálico mais freqüente na infância. Dentre as alterações encontradas estão: a presença das oncoproteínas p53 e HER2, elevado índice mitótico e presença de diferenciação neuronal. O objetivo deste estudo foi determinar a expressão imunoistoquímica (IMQ) dos marcadores Ki-67, NeuN, sinaptofisina, HER2 e p53 em 40 amostras de MB, correlacionando-as com parâmetros clinicopatológicos e com a sobrevida. Vinte e nove pacientes $(72,5 \%)$ apresentaram $20 \%$ ou mais das células positivas para Ki-67. Os pacientes do sexo masculino apresentaram maior expressão do Ki-67 ( $p=0,02)$ e também menor sobrevida $(p=0,002)$. NeuN e sinaptofisina foram negativos em $16(40 \%)$ e $8(20 \%)$ casos, respectivamente. P53 foi positivo em $18(45 \%)$ casos, sendo 11 (61\%) fracamente positivos e 7 (39\%) fortemente positivos. HER2 foi positivo em $23(57,5 \%)$ das amostras e não demonstrou associação estatística com a sobrevida ( $p=0.07)$.
\end{abstract}

PALAVRAS-CHAVE: meduloblastoma, imunoistoquímica, Ki-67, NeuN, sinaptofisina, HER2, p53, sobrevida.

Medulloblastoma (MB) is the most common malignant brain tumor in children, accounting for about $20 \%$ of all primary tumors of the central nervous system (CNS), with a peak of incidence at 5-7 years-old. These tumors have an aggressive behavior and despite treatment, the 5-year survival rate is $60 \%{ }^{1,2}$. For therapeutic and prognostic pur- poses, patients are divided in groups of high and low risk, according to the staging proposed by Chang et al. $(1969)^{3}$, age at the time of diagnosis, and presence of residual tumor $^{4,5}$. A more accurate assessment of risk in children with $\mathrm{MB}$ can be done using a combination of clinical, histopathologic, and molecular prognostic factors ${ }^{4,6,7}$.

\footnotetext{
'Postgraduate Program in Pathology, Fundação Faculdade Federal de Ciências Médicas de Porto Alegre RS, Brazil (FFFCMPA): 'Master student, Graduate Program in Pathology, FFFCMPA; ${ }^{2}$ Undergraduate Medical Student of the FFFCMPA; ${ }^{3}$ Neurologist; M.D. and PhD: Medical Clinic by UFRGS. Adjunct Professor of Human Anatomy, FFFCMPA; ${ }^{4}$ Neurologist, MD, PhD, Substitute Professor of Neurology at FFFCMPA; ${ }^{5}$ Pathologist, MD, PhD, FFFCMPA, Substitute Professor, Department of Pathology, FAMED - UFRGS; ' Professor Emeritus, Reader in Pathologic Anatomy, FFFCMPA, Neuropathologist, Full Professor of Pathologic Anatomy, FFFCMPA; ${ }^{7}$ Biologist, Master in Neuroanatomy by UFRGS, Doctor in Cellular and Tissue Biology by USP, Adjunct Professor of Histology, FFFCMPA. Financial support provided by CAPES, PROAP and Fundação Faculdade Federal de Ciências Médicas de Porto Alegre, RS.
}

Received 21 November 2007, received in final form 14 April 2008. Accepted 29 April 2008.

Dra. Rosalva Thereza Meurer - Rua Sarmento Leite 245 - 90050-170 Porto Alegre RS - Brasil. E-mail: rosalvameurer@hotmail.com 
MBs are among the intracranial tumors with fastest cellular proliferation ${ }^{6}$. Studies show that the Mitotic Index (MI) determined by Ki-67 (MIB-1) above $20 \%$ is correlated with a worse prognosis ${ }^{8}$. NeuN and synaptophysin are commonly used as markers of neuronal differentiation in brain tumors, mainly in heterogeneous tumors such $\mathrm{MBs}^{9,10}$. HER2 is a proto-oncogene that has been largely studied and related with bad prognosis in cancer. In MB, investigations of HER2 expression have demonstrated a consistent association between the expression of this gene and a worse prognosis ${ }^{11-13}$. TP53 gene mutations are one of the most frequent genetic alterations observed in tumors. Increased immunohistochemical expression of p53, particularly when staining is intense, has been associated with a worse prognosis in $\mathrm{MB}^{14,15}$.

This study was designed to evaluate the immunohistochemical expression of Ki-67, NeuN, synaptophysin, HER2 and p53 in patients with MBs and to establish their correlation with clinicopathologic markers as histological subtype, presence of residual tumor, gender, age, and overall survival.

\section{METHOD}

\section{Studied sample}

A retrospective study carried out using 40 samples of tumor tissue collected from patients between 1 and 44 years of age who had been submitted to total or partial resection of cerebellar MB at hospitals Santo Antônio of the Complexo Hospitalar Santa Casa of Porto Alegre, and São Lucas of PUCRS, with anatomopathological diagnosis of MB from Jan 1996 to Jan 2005. The anatomopathological records were reviewed and reassessed by two researchers. The cases were classified into classic MB or desmoplastic MB based on hematoxylin-eosin (HE) and reticulin staining. The samples used in this study were obtained from the first surgical procedure of the patients. Patient records were reviewed as for gender, age at the time of diagnosis, partial or total tumor resection, post-operative treatment, presence of metastasis, recurrence, and death. Patients with incomplete data regarding these variables were excluded from the study. Knowledge of the death cases was obtained through the death certificates provided by the responsible agency.

\section{Immunohistochemical reactions}

For the immunohistochemical studies we used tumor tissue fixed in formalin and included in paraffin. The blocks were cut into $3 \mu \mathrm{m}$ thick sections, deparaffinized and rehydrated for the performance of the technique. The streptoavidin-biotin-peroxidase method (kit LSAB + Peroxidase DakoCytomation ${ }^{\circledR}$ ) was used for detection of proteins Ki-67, synaptophysin, NeuN, HER2 and p53. The antigenic recuperation was performed with sodium citrate $(\mathrm{pH} 6.0)$ heated in double boiler $\left(95-98^{\circ} \mathrm{C}\right)$ for $30 \mathrm{~min}$. Endogenous peroxidase activity was blocked using two baths of 10 min in hydrogen peroxide $\left(\mathrm{H}_{2} \mathrm{O}_{2}\right) 30 \mathrm{~V}$, at $5 \%$, in methanol. Unspecific proteins were blocked using normal horse serum for 30 min. Incubation with primary antibodies (Table 1) was performed overnight at $4{ }^{\circ} \mathrm{C}$. Incubation with secondary antibody and tertiary antibody was performed for $30 \mathrm{~min}$ at room temperature. As negative control we used the same tissues, incubated with the same antibodies except for the primary one, which was replaced by normal horse serum. The antigen-antibody binding was visualized with the DAB chromogen (diaminobenzidin). Counterstaining was with Harris hematoxylin; the slides were dehydrated and mounted in synthetic resin.

The indexes of markers $\mathrm{Ki}-67$ and p 53 were calculated as percentage of stained nuclei in 1,000 cells. The counting was performed by 2 researchers under light microscopy. Cells were considered positive if their nucleus was stained brown. For p53 the positive samples were divided into 2 groups according to the intensity of staining: weak or strong. For the evaluation of NeuN and synaptophysin the following key was used: (+) 1-10\%, (++) $11-50 \%,(+++)>50 \%$ of tumor cells stained. As regards HER2, positive samples were considered as those which showed reactivity in either the membrane or the cytoplasm. If the counts by the two researchers differed by over $20 \%$, a third researcher was summoned to do a new count and the mean of the three counts was used.

\section{Statistical analysis}

Comparisons between the groups were calculated by ANOVA parametric test, Student's t test and Fisher's exact test. For survival the Kaplan-Meier test was used. The magnitude of association among the variables death versus clinical aspects and immunohistochemical markers was measured by Hazard Ratio (HR),

Table 1. Immunohistochemistry in medulloblastomas.

\begin{tabular}{ccccc}
\hline Antibody (clone) & dilution & Manufacturer & Catalog No. & Positive control \\
\hline Ki-67 (MIB-1) & $1 / 300$ & DakoCytomation $^{\circledR}$ & M7240 & Palatine tonsil \\
NeuN (MAB77) & $1 / 1000$ & Chemicon $^{\circledR}$ & MAB377 & Nervous tissue (brain) \\
Synaptophysin SY38 & $1 / 200$ & DakoCytomation $^{\circledR}$ & M0776 & Adrenal gland \\
HER2 (CB11) & $1 / 40$ & Novocastra $^{\circledR}$ & NCL-L-CB11 & Breast \\
P53 (DO-7) & $1 / 100$ & DakoCytomation $^{\circledR}$ & M7001 & Breast \\
\hline
\end{tabular}


obtained by Cox Regression model and $95 \%$ confidence intervals (CI). The level of significance used was $\alpha \leq 0.05$. The data were analyzed with the SPSS 12.0 software package (Chicago, IL, USA).

\section{Ethical aspects}

The project was approved by the Research Ethic Committee of the Santa Casa de Porto Alegre (protocol number 205/04).

\section{RESULTS}

\section{Clinicopathologic findings}

The studied sample comprised 40 patients between 1 and 44 years of age (mean 11.35 years). Thirty-two patients $(80 \%)$ were under 15 years of age at the time of diagnosis, and 8 patients (20\%) were over that age. Twenty patients $(50 \%)$ were males and 20 were females (50\%). Twenty-six patients $(76.47 \%)$ were submitted to total tumor resection and $8(23.53 \%)$ to partial resection. For 6 patients there was no reference of tumor resection in the medical record. Concerning to the histological classification, 29 (72.50\%) were diagnosed as classic MB and 11 (27.50\%) as desmoplastic MB. The desmoplastic variant was more common in patients over 15 years old. No statistical significance was found between histological subtype, age, type of tumor resection and survival (Table 2). Males presented a significantly reduced survival as compared to females $(p=0.002$ ) (Table 2 and Fig 1). We did not find information about patients' staging in the medical archives.

\section{Immunohistochemistry}

Ki-67 - The percentage of Ki-67-positive cells (Fig 2A) was $1.8-54 \%$. Twenty-nine patients had over $20 \%$ of positive cells and 11 showed less than $20 \%$ of positive cells (Table 3). Males presented a greater percentage of stained

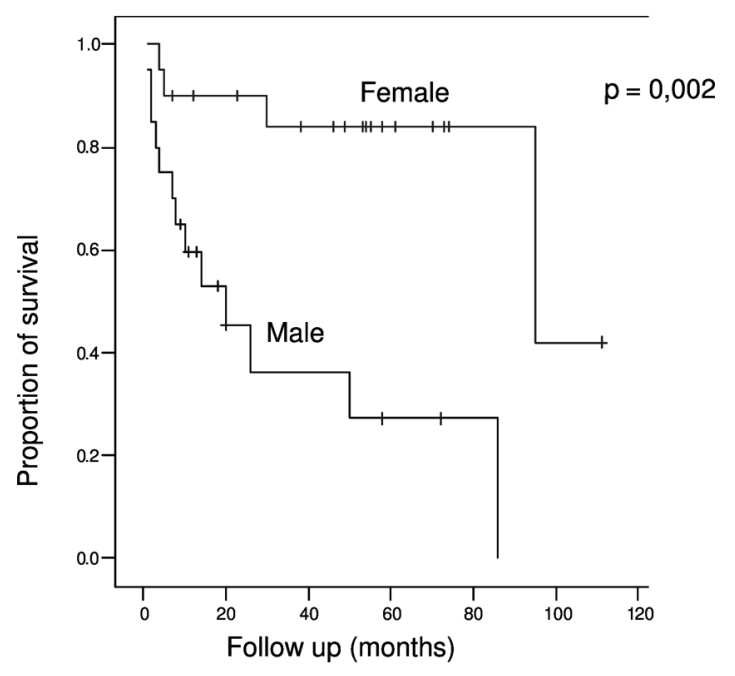

Fig 1. Kaplan-Meier curve representing patient survival according to sex.
Table 2. Occurrence of death in patients with medulloblastoma according to clinical parameters.

\begin{tabular}{lccccc}
\hline Variable & $\mathrm{n}$ & Death (\%) & $\mathrm{RR}$ & $\mathrm{Cl} 95 \%$ & $\mathrm{P}$ \\
\hline $\begin{array}{l}\text { Sex } \\
\quad \text { male }\end{array}$ & 20 & $13(65)$ & 7.15 & $2.0-25.6$ & 0.002 \\
$\quad$ female & 20 & $4(20)$ & & & \\
$\begin{array}{l}\text { Age } \\
\quad<15 \text { years }\end{array}$ & 32 & $16(50)$ & 6.30 & $0.83-47.9$ & 0.076 \\
$\quad \geq 15$ years & 8 & $1(12.5)$ & & & \\
$\begin{array}{l}\text { Subtype } \\
\quad \text { classic }\end{array}$ & 29 & $14(48.3)$ & 1.97 & $0.56-6.9$ & 0.288 \\
$\quad$ desmoplastic & 11 & $3(27.3)$ & & & \\
$\begin{array}{l}\text { Surgery } \\
\text { total }\end{array}$ & 26 & $9(34.6)$ & 0.83 & $0.26-3.15$ & 0.782 \\
$\quad$ partial & 8 & $4(50)$ & & & \\
\hline
\end{tabular}

HR, Hazard Ratio (or relative risk) obtained in model of proportional odds ratio of Cox; $\mathrm{Cl} 95 \%$, confidence interval of $95 \%$; $p$, statistical significance.

Table 3. Occurrence of death in patients with medulloblastoma according to immunohistochemical markers.

\begin{tabular}{lccccc}
\hline Variable & $\mathrm{n}$ & Death (\%) & $\mathrm{RR}$ & $\mathrm{Cl} 95 \%$ & $\mathrm{p}$ \\
\hline $\begin{array}{l}\text { Ki67 } \\
\geq 20 \%\end{array}$ & 29 & $13(44.8)$ & 1.53 & $0.49-4.78$ & 0.46 \\
$<20 \%$ & 11 & $4(36.4)$ & & & \\
$\mathrm{p} 53$ & & & & & \\
$\quad$ positive & 18 & $8(44.4)$ & 1.08 & $0.41-2.81$ & 0.88 \\
$\quad$ negative & 22 & $9(40.9)$ & & & \\
$\begin{array}{l}\text { HER2 } \\
\quad \text { positive }\end{array}$ & 23 & $12(52.2)$ & 2.92 & $0.93-9.12$ & 0.07 \\
$\quad$ negative & 17 & $5(29.4)$ & & & \\
$\begin{array}{l}\text { NeuN } \\
\quad \text { positive }\end{array}$ & 24 & $12(50.0)$ & 1.21 & $0.41-3.56$ & 0.72 \\
negative & 16 & $5(31.3)$ & & & \\
$\begin{array}{l}\text { Synaptophysin } \\
\text { positive }\end{array}$ & 32 & $14(43.8)$ & 1.00 & $0.28-3.54$ & 0.99 \\
negative & 8 & $3(37.5)$ & & & \\
\hline
\end{tabular}

HR, Hazard Ratio (or relative risk) obtained in model of proportional odds ratio of Cox; $\mathrm{Cl} 95 \%$, confidence interval of 95\%; p, statistical significance.

Table 4. Immunoreactivity results to Ki-67 as regards histological subtype, sex and $p 53$.

\begin{tabular}{lccc}
\hline Variable & $\mathrm{N}$ & Mean Ki-67 (\%) & $\mathrm{p}$ \\
\hline $\begin{array}{l}\text { Histological subtype } \\
\quad \text { classic }\end{array}$ & 29 & 29.42 & \\
$\quad$ desmoplastic & 11 & 20.84 & 0.05 \\
Sex & & & \\
$\quad$ male & 20 & 31.57 & \\
$\quad$ female & 20 & 22.54 & 0.02 \\
p53 & & & \\
$\quad$ negative & 22 & 22.24 & \\
$\quad$ weak & 11 & 32.86 & \\
$\quad$ strong & 7 & 33.05 & 0.02 \\
\hline
\end{tabular}




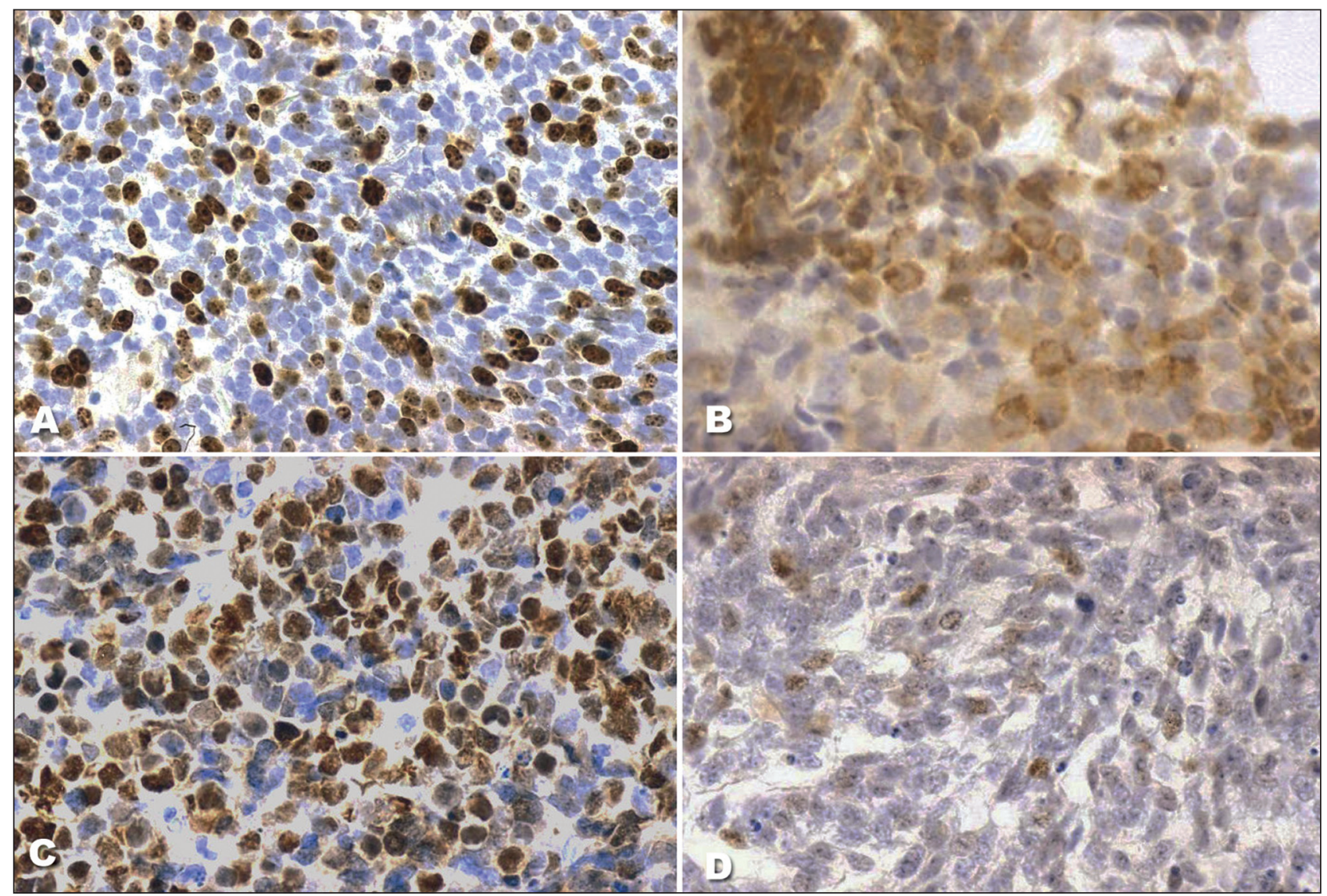

Fig 2. Photomicrographs of medulloblastoma. (A) immunoreactive cells to antibody Ki-67 (40x); (B) positive reaction to antibody HER2 in membrane and cytoplasm (40x); (C) cells with strong reaction to $p 53$; (D) cells with weak reaction to $p 53$ (40x).

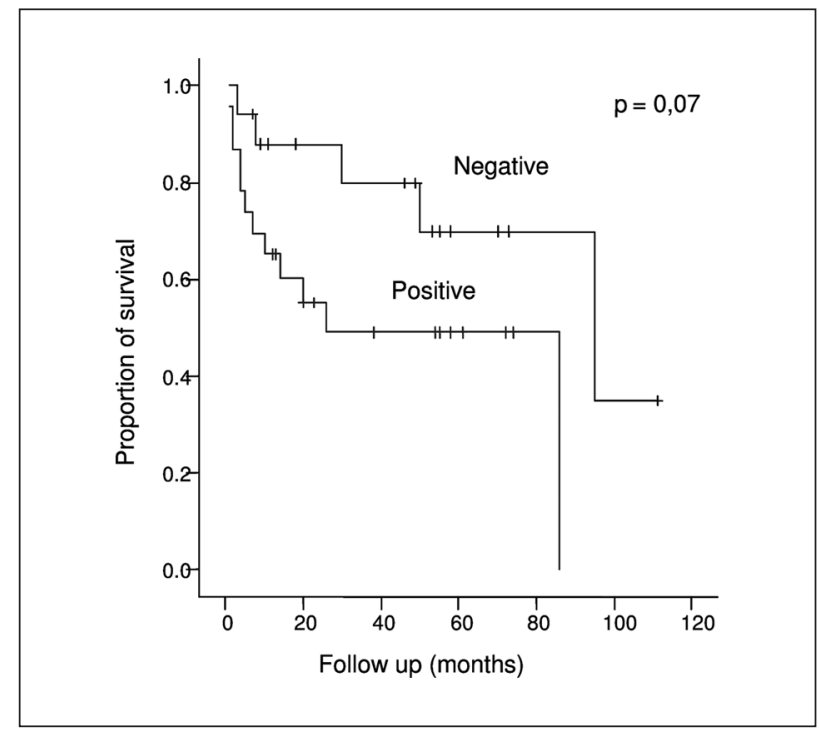

Fig 3. Kaplan-Meier curve representing patient survival according to immunohistochemical expression of HER2.

cells than females (Table 4). Histologically, classic MB showed greater $\mathrm{Ki}-67$ expression than desmoplastic MB (Table 4). No significant statistical correlation was found between $\mathrm{Ki}-67$ expression and survival and the other clin- ical variables studied, nor with markers NeuN, synaptophysin and HER2.

NeuN and synaptophysin - NeuN e synaptophysin were positive in $24(60 \%)$ and $32(80 \%)$ cases, respectively. There was no correlation between immunohistochemical expression of NeuN and synaptophysin and the clinicopathologic characteristics.

p53 - P53 was positive in 18 samples (45\%). Seven samples presented strong positive reaction (Fig $2 \mathrm{C}$ ) and 11 weak reaction (Fig 2D). There was no statistical significance between $\mathrm{p} 53$ immunohistochemical expression and survival. We found a statistically significant correlation between p53 and Ki-67 ( $p=0.02)$. P53-negative patients presented lower $\mathrm{Ki}-67$ values than $\mathrm{p} 53$-positive patients (Table 4).

HER2 - Twenty-three (57.5\%) samples expressed HER2 (Fig 2B) and showed a trend to association with poorer survival ( $p=0.07$ ) (Fig 3).

\section{DISCUSSION}

$M B$ is a cerebellar embryonal tumor of grade IV (WHO) and it is also the most frequent brain tumor in children, accounting for $15-25 \%$ of brain tumors in this age bracket ${ }^{9}$. Despite surgical treatment, radiotherapy and chemothera- 
py, 50-60\% of the affected individuals survive 5 years after the diagnosis ${ }^{16}$. Currently, there are no accurate clinical prognostic markers except for tumor dissemination via liquor at the time of diagnosis ${ }^{4,5,17}$, hence the need for validating new indicators of MB biological behavior. In order to assess the prognostic potential of Ki-67, NeuN, synaptophysin, HER2 and p53 in MB we have analyzed these proteins in 40 samples using the immunohistochemical technique and have correlated the results with clinicopathological parameters such as: age, sex, histological subtype, presence of residual tumor, and survival. In our study, sex showed a great impact on survival rate. Male patients presented significantly reduced survival as compared to females $(p=0.002)$. This finding was also reported by Jaros et al. and Weil et al. ${ }^{14,18}$. As previously described by other authors ${ }^{2,15}$, the variables age, histological subtype, and presence of residual tumor did not have a statistically significant correlation with survival.

The immunohistochemical expression of protein $\mathrm{Ki}$ 67 is strongly associated with cellular proliferation and it is a widely used marker to evaluate the mitotic index in tumors. MBs are rapidly proliferating tumors, and they have a quite elevated Ki-67 expression ${ }^{7,15,19-21}$. In our study, the mean number of Ki-67-positive cells was $27.05 \%$. This finding was not statistically significant concerning patient survival, even after stratification of the sample (Table 3), as suggested by Ito et al. ${ }^{8}$. These authors, studying a population of 32 patients, have noted a significant association between the mitotic index and the prognosis. In this study, Ki-67-positive cells above $20 \%$ was associated with a worse prognosis. Miralbell et al. ${ }^{22}$ and Urberuaga et al. ${ }^{19}$ suggested that $\mathrm{Ki}-67$ expression is probably not a determinant factor of prognosis in MB. In the present study, $\mathrm{Ki}-67$ expression was greater in male patients $(p=0.02)$, who also presented shorter survival $(p=0.002)$. These data could suggest a possible connection between high mitotic index and shorter survival.

NeuN and synaptophysin are markers of neuronal differentiation ${ }^{6,9}$. The prognostic value of these markers is conflicting in the literature ${ }^{14}$. In our study, immunohistochemical expression of NeuN and synaptophysin were not correlated with prognosis.

TP53 is a gene that plays a key role in the regulation of the cell cycle and apoptosis. In normal cells, protein p53 is present in low levels and is generally undetectable through immunohistochemistry. High levels of p53 expression in immunohistochemical reactions are related with deletions or genetic mutation points ${ }^{23}$. Expression and mutation of protein $\mathrm{p} 53$ are rare events in $\mathrm{MBs}^{9,14}$. In our study, 18 cases showed p53-positive cells, but, neither the percentage of stained cells, nor the intensity of staining were correlated with survival $(p=0.88)$. Studies conducted by Jaros et al. ${ }^{14}$ and Woodburn et al..$^{15}$ showed that strong immunohistochemical expression of protein p53 is associated with bad prognosis, yet there is no connection between prognosis and number of stained cells. An interesting finding observed in this study was a correlation between immunohistochemical expression of Ki-67 and $p 53$. Patients with $\mathrm{p} 53$-negative cells presented lower Ki-67 values than patients with $\mathrm{p} 53$-positive cells. This may be related to the functional loss of mutated p53, which would allow a greater proliferation of neoplastic cells.

Proto-oncogen HER2 is located on chromosome 17 and codes for a membrane receptor glycoprotein, p185, which is thus called HER2 protein or receptor ${ }^{10}$. Immunohistochemical expression of this receptor is associated with worse prognoses in several human neoplasias, including $\mathrm{MB}^{11-13,17}$.

Gilbertson et al." have demonstrated that protein HER2 is expressed in most MBs. In a retrospective study of 55 cases of MB, the prognostic value of HER2 expression was dependent on the percentage of positive tumor cells. Patients with more than $50 \%$ of positive tumor cells presented a lower survival rate $(p=0.0049)$. These findings were confirmed later by Gilbertson et al. ${ }^{24}$. In a study with 41 patients with MB, Herms et al. ${ }^{2}$ detected a smaller immunohistochemical expression of HER2 (13\%) in 45 cases of $\mathrm{MB}$, but they also found a smaller survival rate for patients with positive HER2, particularly in those diagnosed before 3 years of age. Gajjar et al. ${ }^{2}$ analyzed 81 cases of MB by the Western blot technique and detected HER2 expression in $40 \%$ of cases. HER2 expression in this study proved to be an independent factor of bad prognosis $(p=0,031)$, showing a greater impact if combined with clinical characteristics of the patients. In our study, all patients who were clinically considered as "low risk and HER2-negative" were alive within 5 years, as compared to $54 \%$ of the patients considered as "low risk and HER2-positive" $(p=0.001)$.

The immunohistochemical expression of HER2 in this study was positive in $23(57.5 \%)$ of the samples and presented a trend to association with poorer survival $(p=0.07)$. Some discrepancies about HER2 immunoreactivity found in the literature may be related to the morphological characteristic of MB cells, which have a scarce cytoplasm, making it difficult to ascribe the immunohistochemical staining to the membrane or to the cytoplasm. In our study, staining in either cytoplasm or membrane was considered as positive. The same approach was used by Herms et al., $\mathrm{Nam}$ et al. and Gilbertson RJ et al. ${ }^{12,25,23}$. Concerning to the survival rate, the results obtained in this study are in agreement with those by Nam et al. ${ }^{25}$ and Ray et al. ${ }^{17}$.

In conclusion, in our study, the only variable that showed influence in patients' survival rate and which might 
be considered as a potential prognostic factor in $\mathrm{MB}$, was the greatest proliferative index measured for $\mathrm{Ki}-67$ in male patients, who presented a statistically significant shorter survival. P53 also was associated with a greater proliferative index. Considering the other immunohistochemical markers studied, particularly HER2, we suggest that further investigations are needed, with larger samples, based on the tendency towards an association found by us.

\section{REFERENCES}

1. Ellison DW, Clifford SC., Gajjar A, Gilbertson J R. What's new in neuro-oncology? Recent advances in medulloblastoma. Eur J Paediat Neurol 2003;7:53-66

2. Gajjar A, Hernan R, Kocak M, et al. Clinical, histopathologic, and molecular markers of prognosis: toward a new disease risk stratification system for medulloblastoma. J Clin Oncol 2004;22:984-993.

3. Chang C H, Housepian EM, Herbert C JR. An operative staging system and a megavoltage radiotherapeutic technic for cerebellar medulloblastomas. Radiology 1969;93:1351-1359.

4. Gilbertson JR. Medulloblastoma: signalling a change in treatment. Lancet Oncol 2004;5:209-218.

5. Rutkauskiené G, Labanauskas L, Jarusevicius L. The results of the treatment of childhood medulloblastoma with radiotherapy at Kaunas University of Medicine Hospital in 1994- 2000. Medicina (Kaunas) 2006;42(1).

6. Ellison D. Classifying the meduloblastoma;insights from morphology and molecular genetics. Neuropathol App Neurobiol 2002;28:257-282.

7. Grotzer MA, Geoerger B, Janss AJ, et al. Prognostic significance of Ki67(MIB-1) proliferation index in childhood primitive neuroectodermal tumors of the central nervous system. Med Pediat Oncol 2001;36:268-273.

8. Ito S, Hoshino T, Prados MD, Edwards MSB. Cell kinetics of medulloblastoma. Cancer 1992;70:671-678.

9. Lantos PL, Louis DN, Rosenblum MK, Kleihues P. Tumours of the nervous system. In Graham DI, Lantos PL (eds). Greenfield's neuropathology. London: Arnold 2002;2:882-894.

10. Preusser M, Laggner U, Haberler C, et al. Comparative analysis of NeuN immunoreactivity in primary brain tumours: conclusions for rational use in diagnostic histopathology. Histopathology 2006;48:438-444.

11. Gilbertson RJ, Pearson ADJ., Perry RH, et al.. Prognostic significant of the c-erbB2 oncogene product in childhood medulloblastoma. Br J Cancer 1995;71:473-477.

12. Herms JW, Behnke J, Bergmann M, et al. Potential prognostic value of C-erbB-2 Expression in Medulloblastomas in very young children. J Pediat Hematol/Oncol 1997;19:510-515.

13. Gilbertson RJ. ERBB2 in pediatric Cancer: innocent until proven guilty. The Oncologist 2005;7:508-517.

14. Jaros E, Lunec J, Perry RH, et al. P53 protein overexpression identifies a group of central primitive neuroectodermal tumours with poor prognosis. Br J Cancer 1993;68:801-807.

15. Wooburn RT, Azzarelli B, Montebello J.F, Goss IE. Intense p53 staining is a valuable prognostic indicator for poor prognosis in medulloblasto$\mathrm{ma} /$ central nervous system primitive neuroectodermal tumors. J Neuro-Oncol 2001;52:57-62.

16. Brandes AA, Paris MK. Review of the prognostic factors in medulloblastoma of children and adults. Crit Rev Oncol/Hematol 2004;50:121-128.

17. Ray A, Ho M, Ma J, et al. A clinicobiological model predicting survival in medulloblastoma. Clin Cancer Res 2004;10:7613-7620.

18. Weil MD, Lamborn K, Edwards MS, Wara WM. Influence of a child's sex on medulloblastoma outcome. JAMA 1998;13:279:1474-1476.

19. Urberuaga A, Navajas A, Burgos J, Pijoán JI. A review of clinical and histological features of Spanish paediatric medulloblastomas during the last 21 years. Childs Nerv Syst 2005;22:466-474.

20. Ferrari AF, Araújo MBM, Aguiar PH, Plese JPP. Medulloblastoma: evaluation of proliferative index by monoclonal antibody Mib-1, its prognostic correlation and therapeutic implications. Arq Neuropsiquiatr 2003;61:3A.

21. Kayaselçuk F, Zorludemir S, Gümürdülü D, et al. PCNA and Ki-67 in central nervous system tumors: correlation with the histological type and grade. J Neuro-Oncol 2002;57:115-121.

22. Miralbell R, Tolnay M, Bieri S, et al. Pediatric medulloblastoma: prognostic value of p53, bcl-2, Mib-1, and microvessel density. J Neuro-Oncol 1999;45:103-110.

23. Soussi T. The p53 tumor suppressor gene: from molecular biology to clinical investigation. Ann N Y Acad Sci 2000;910:121-137; discussion 137-139.

24. Gilbertson RJ, Wickramasinghe C, Herman R, et al. Clinical and molecular stratification of disease risk in medulloblastoma. Br J Cancer 2001;85:705-712.

25. Nam DH, Wang KC, Kim YM, et al. The effect of isochromosome 17q presence, proliferative and apoptotic indices, expression of C-erbB-2, bcl-2 and p53 proteins on the prognosis of medulloblastoma. J Korean Med Sci 2000;15:452-456. 